\title{
Smallholder Farmers' Decision and Level of Participation in the Potato Market in Uganda
}

\author{
Christopher Sebatta1, Johnny Mugisha1, Enid Katungi', \\ Apolo Kashaaru' ${ }^{2}$, Harriet Kyomugisha ${ }^{1}$ \\ ${ }^{1}$ Department of Agribusiness and Natural Resource Economics, Makerere University, Kampala, Uganda \\ ${ }^{2}$ Faculty of Agriculture, Gulu University, Uganda \\ Email: sebattac@gmail.com, jomugisha@agric.mak.ac.ug, e.katungi@cgiar.org, apokatu@yahoo.com, \\ harriet.kyomugisha@gmail.com
}

Received 3 April 2014; revised 20 May 2014; accepted 30 June 2014

Copyright (C) 2014 by authors and Scientific Research Publishing Inc.

This work is licensed under the Creative Commons Attribution International License (CC BY).

http://creativecommons.org/licenses/by/4.0/

cC) (7) Open Access

\begin{abstract}
Smallholder potato farmers in Uganda face many production and marketing challenges including limited access to markets and low surpluses for sale into the market. This study sought to underscore the factors that influence smallholder farmers' decision to participate in the potato market and level of participation in such markets. Data were collected from 200 smallholder potato farmers in Kabale and Mbale districts. Descriptive statistics and a two-stage Heckman model were used to analyse the data. Results indicated that proximity to a village market positively and significantly ( $p \leq 0.05$ ) influenced decision to participate in the potato market. Results of the second stage of the model indicated that non-farm income earned negatively and significantly $(p \leq 0.01)$ affected the potato farmer's level of market participation.
\end{abstract}

\section{Keywords}

Smallholder Farmers, Market Participation, Heckman Model

\section{Introduction}

In most of the developing countries, potato is considered the fourth most important food crop after rice, wheat and maize. [1]-[3] pointed out that since the second half of the 20th century, the relative importance of potato has slowly shifted from developed to developing countries although more potato is still being produced in the former than the latter countries.

Between 1994 and 2008, potato production in Sub Saharan Africa was estimated to have more than doubled from 100 metric tonnes to 290 metric tonnes with $70 \%$ of this growth concentrated in Eastern Africa [1]. This 
increase was attributed to increase in area used to grow potato since average yields have declined considerably due to inadequate use of quality inputs like certified seed and fertilizer. The main drivers of this growth in production are increasing urbanisation and population growth. Urbanisation is estimated to rise from $34 \%$ in 2010 to $47 \%$ by 2015 [4].

Farmer market access is a vital component of market participation. A smallholder farmer can access the market either by selling to a buyer at the farm gate or physically transporting the produce to the market place using available means. A number of scholars have researched about what drives farmers' market access and much has been revealed, for example, [5] [6] found that good road condition and access to information positively influenced farmer participation and access to markets due to their effect on reduction in transaction costs.

[4] [7] and [8] found that the low crop yields were attributed to farmers' failure to use improved inputs leading to lack of competitive production and low market participation. [9] revealed that small plots of land and high costs of inputs had limited the potato yields in Uganda and hence limiting the profits of smallholder producers. [10] puts to light the fact that especially for seed and fertiliser, market failures continue to be pervasive in Sub-Saharan Africa because of high transaction costs, risks and low economies of scale.

\section{Potato Production in Uganda}

Potato was introduced into East Africa in the 1880s by the British. In Uganda, its production is concentrated in Kigezi highlands of Kabale and Kisoro in the south-west, Mountain Elgon districts of Mbale and Kapchorwa in eastern Uganda with highlands between $1500 \mathrm{~m}$ and $3000 \mathrm{~m}$ above sea level [11]. The Kigezi highlands produce about $60 \%$ of total Ugandan potato output [1] and South Eastern Uganda contributes 10\%. The remaining 30\% comes from the districts of Mubende, Nebbi, Masaka, Mbarara and Rakai [4] [9]. In recent years, the introduction of lowland varieties extended the crop to other regions like the central and west Nile as a commercial activity and increased potato output over the years [4] [9].

The government of Uganda has been committing resources towards increasing productivity and creating sustainable market linkages for farmers through the Plan for Modernisation of Agriculture (PMA) from which National Agricultural Advisory Services (NAADS) was curved. It has also significantly funded research in crop diseases and improved varieties under NARO [12]. Potato production has had one of the highest growth rates in Uganda in the last 25 years of 14\% [4] [13].

\section{Determinants of Smallholder Farmer Market Participation}

\subsection{Social-Demographic Characteristics}

Social-demographic characteristics of the farmers play a very crucial role in either promoting or impeding their participation in agricultural markets. In this sub-section, key social-demographic factors related to market participation of smallholders are reviewed.

[14] using a two-stage Heckman model found that belonging to a farmer's group, household size and distance to the market significantly influenced extent of farmers' participation in banana markets. The author found that farmers who belonged to a farmers' group had cohesion in terms of gaining and sharing knowledge as well as capacity to produce more for a marketable surplus. [15] also suggested collective action in form of farmer cooperatives or groups to increase smallholder market participation. [16], however added that forming farmer groups though recognised as essential for efficient farmer learning, receiving external support and achieving economies of scale, it must be accompanied by incentives to participate in markets.

[17] on the other hand, found that household crop market participation was determined by literacy of the head of household, nearness to the market place and household's market orientation, which is the making of production decisions based on market signals. [18]-[20] found that transaction cost-related factors such as geographical location, market information sources, and travel time to the nearest market, labour availability, farming experience, gender of household head, off-farm income and household asset base affect smallholders' likelihood and intensity of participation in markets.

Household Assets that Affect Produce Volumes Available for Sale

In this section, literature related to cash and non-cash assets that influence the volume of produce sold in the markets by smallholder farmers is reviewed. The importance of these assets in generation of marketable sur- 
pluses and their significance in enhancing market participation is put in focus.

[21] found size of cultivable land, human and physical capital to be important factors in inducing smallholder market participation. Farmers with bigger cultivable land were found to participate more because of their ability to produce bigger volumes that ensured marketed surpluses. [22] found household labour to be an influential but cheaper asset that leads to higher production volumes and positively influences farmers' market participation.

[23] used an asset-based approach to study patterns of household market participation in Mozambique. The authors found that private household assets especially land, livestock and farm equipment positively affected crop market participation. [24], studying market participation in staple grains, found that barriers to participation in markets by smallholders were mainly land, livestock, capital and improved technologies like farm equipment needed to generate a surplus that influenced market participation. [25] on the other hand found that households with larger land holdings per adult member sold larger volumes of their produce as compared to those with smaller land holdings. The authors further found that households with larger livestock endowments produced and sold more crop produce. They explained that it was because the households used manures from the livestock to enhance crop yields. However, [17] pointed out that ownership of livestock by a household negatively affected its participation in the crop market because it distracts the farmer into an alternative source of income.

In a related study, [26] found that price had an important influence on the level of farmers' market participation in cassava markets which is supported by economic theory that price induces increased supply. [27] also asserted that better output price and market information were key incentives for increased sales in the market, while household size and non-farm income significantly reduced the sales of vegetables in the market. [26] further found that the probability of market participation declined with declining farm size for sellers of cassava but increased with farm sizes for buyers though not significant in either case.

[4] [7] [8] found that the low crop yields were attributed to farmers' failure to use improved inputs leading to lack of competitive production and low market participation. [9] revealed that small plots of land and high costs of inputs had limited the potato yields in Uganda and hence limiting the profits of smallholder producers.

[10] puts to light the fact that especially for seed and fertiliser, market failures continue to be pervasive in Sub-Saharan Africa because of high transaction costs, risks and low economies of scale. [28] noted that the green revolution in Asia spurred economic growth and reduced rural poverty significantly because many smallholders accessed inputs like improved seed and fertiliser profitably. [29] stated that most smallholders lack the land and other resources to produce a surplus.

Even though there is a lot of research done on farmer market participation, many of the studies seem to concentrate on grain staples especially maize. Little attention has been given to perishables like potato yet they are increasingly being commercialised for household income generation. Therefore, this study set out to address the following hypotheses: what are the factors responsible for taking the decision of entering the market? And what determines the volume of potatoes sold at the market?

\subsection{Study Objectives}

The main objective of this study was to determine factors that influence potato farmers' market participation and economic viability of value addition by farmers. The specific objectives were to:

1) Characterise potato farmers according to market participation.

2) Determine factors that influence the decision of smallholder farmers to participate in the market as sellers.

3) Determine the factors that influence the level of potato smallholder farmers' market participation as sellers.

\subsection{Study Hypotheses}

The study was guided by the following hypotheses:

1) What are the factors responsible for smallholder farmers' decision to enter the market?

2) What determines the volume of potatoes sold at the market by a smallholder farmer?

\section{Methods and Procedures}

\subsection{Study Area and Sampling Procedure}

The study was conducted in Kabale and Mbale districts in South Western and Eastern Uganda respectively. The districts were selected purposively for being the major potato producing areas in Uganda. The main economic activities in the study area are growing crops especially potato, sorghum and coffee and rearing animals. A random 
sampling technique based on farmers' participation in potato markets was adopted in choosing the respondents. Two sub-counties from Kabale and one from Mbale district were purposively selected to represent the leading potato producing areas. Two parishes from each sub-county were also purposively selected followed by random sampling of respondents where 60 farmers were selected from Mbale and 140 from Kabale in proportion of the area's contribution to national potato output giving a total sample of 200 farmers.

Data were collected between December 2011 and May 2013 to capture data for the two major potato growing seasons in the study area using a pre-tested self administered structured questionnaire. Data was collected on potato farm gate prices for the two seasons before the interviews, marketing and market conditions related to market access and infrastructure, production and information access as well as inputs used in production, household endowments, credit access, farming experience, farm characteristics and household socio-demographic characteristics.

\subsection{Analytical Methods}

The analytical methods used in this study included the two-stage Heckman model as previously used by [30][32]. The two-stage Heckman model was run to determine factors affecting farmers' decision to participate and level of market participation and test the hypothesis that: High transaction costs associated with long distances from the farm to market locations limits farmer participation in potato markets. The model was also employed to test the second hypothesis that membership in a farmer group/cooperative positively influences smallholder farmers' decision to participate in markets. When market participation is defined as quantity or proportion of harvested output that is marketed, the researcher does not observed the dependent variable for households that do not participate in the market. Tobit or Heckman models have been used to estimate the effect of hypothesized variables on market participation. [33] stated that the censored regression or Tobit model is appropriate when the dependent variable is censored at some upper or lower bounds as an artefact of how the data are collected. On the Heckman model, the same authors noted that estimation of the first stage equation of the model as a probit model assumes that the errors are homoskedastic.

Variables in the two stages differed because originally, such models were estimated using the Tobit model that accounts for the clustering of zeros due to non-participation. However, a major limitation with the Tobit model is that it assumes that the same set of parameters and variables determine both the probability of market participation and the level of transactions. A two-step model however relaxes these assumptions by allowing different mechanisms to determine the discrete probability of participation and the level of participation [34]. These models allow for a separation between the initial decision to participate and the decision of how much to sell. In this case, it is assumed that some right hand side variables may affect differently the decision to participate at all and the decision on the level of participation.

Variables used in the model were; Age of farmer (Years), Farmer's gender ( $1=$ male, $0=$ female), Farmer's household size, Potato marketing experience (years), Farmer's monthly non-farm income (UGX), Value of farming equipment owned (UGX), Distance to nearest potato market (km), Farmer being a member of a group or cooperative, access to a village market, Farmer's education level (Years spent at school), Farmer has other food sources apart from potato, Road condition to nearest market, number of extension visits made to the farm specifically on potato per year and average Price of potato (Shillings per kg).

The Heckman model was stated as:

$$
\begin{gathered}
y_{1 i}=0 \text { if } \quad S_{n i} \leq 0 \\
y_{1 i}=1 \text { if } \quad S_{n i}>0
\end{gathered}
$$

where;

$y_{1}$ is the binary response

$S_{n i}$ is the quantity of potato sales made by a farmer $i$.

The participation equation can then be written as:

$$
y_{1}^{*}=\beta_{1 I} X_{1 i}+\varepsilon_{1 i}
$$

where $y_{1}^{*}$ is a latent variable, which is the utility the farmer gets from participating in the market.

The binary model is then stated as:

$$
y= \begin{cases}1, & \text { if farmer sells any potato } \\ 0, & \text { other wise }\end{cases}
$$


In specific terms, the probit model in stage one of estimation is stated as;

$$
\operatorname{Pr}\left(y_{1}\right)=f\left(x_{1}, x_{2}, \cdots, x_{15}, e\right)
$$

where, $\operatorname{Pr}\left(y_{1}\right)$ is the probability of a farmer making a decision to sell potato into a market or not, $X_{1} \cdots X_{15}$ are the variables specified in Table 1 and $\varepsilon$ the normally distributed error term. In the second stage of the Heckman model, OLS are estimated to test the effect of hypothesised factors on the level of participation measured by the amount of potato sales in the market. The model is stated as;

$$
S_{n}=f\left(y_{1}, y_{2}, \cdots, y_{13}, \varepsilon\right)
$$

where,

$S_{n}$ is the volume of potato sold annually in the market by a smallholder farmer in two seasons.

$y_{1} \cdots y_{11}$ are the variables that were aPriori hypothesised to affect the volume of potato sold by a farmer in the market and $\varepsilon$, the error term.

\section{Empirical Estimation Procedure and Hypothesis Testing}

Estimation of the model outlined above in Equations (1) to (6) followed a series of regression diagnostics. Variables used in both stages of the model were first checked for normality using Exploratory Data Analysis using the coefficient of kurtosis and skewness. Regression diagnostics included tests for multi-collinearity, self-selection bias and heteroscedasticity. Multicollinearity was tested using the variance inflation factor (VIF) while heteroscedasticity was checked using Breusch-Pagan/Cook-Weisberg tests [35]. Variables used in the first stage of the Heckman model are shown in Table 1 for factors that affect farmers' decision to participate in the market.

Table 1. Explanatory variables hypothesised to affect market participation decision.

\begin{tabular}{cl}
\hline Variable & \multicolumn{1}{c}{ Variable description } \\
\hline Pr (Potsal) & \multicolumn{1}{c}{ Probability that a farmer sold potato or not } \\
\hline & Household characteristics \\
\hline$X_{1}$ & Age of farmer (Years) \\
$X_{2}$ & Farmer's gender (1 = male, 0 = female) \\
$X_{3}$ & Potato farming experience (years) \\
$X_{4}$ & Farmer's education level (Years spent at school) \\
$X_{5}$ & Farmer's household size \\
$X_{6}$ & Farmer has other food sources apart from potato \\
& Farmer endowments (Assets) \\
$X_{7}$ & Value of livestock owned (UGX) \\
$X_{8}$ & Value of farmer's household durables (UGX) \\
$X_{9}$ & Farmer's monthly non-farm income (UGX) \\
& Information access \\
$X_{10}$ & Distance to nearest potato market (km) \\
$X_{11}$ & Number of extension visits made to the farm specifically on potato per year \\
$X_{12}$ & Road condition to nearest potato market (1 = good, 0 = poor) \\
$X_{13}$ & Availability of a village market \\
& Other factors \\
& Average Price of potato (Shillings per kg) \\
\hline 15 & Time farmer takes to walk to the garden (minutes) \\
\hline
\end{tabular}


The second stage variables of the model for factors determining farmers' level of market participation are shown in Table 2.

\section{Results and Discussion}

Table 3 above shows the descriptive statistics related to the sampled potato farmers. Results indicate that there was a significant difference $(\mathrm{P} \leq 0.05)$ between total land holding owned by potato sellers and non-sellers. Sellers owned an average of 1.4 ha while non-sellers owned more land at 2.6 ha. The explanation for this result is that land is a scarce resource in the study area and it is more likely that those with bigger pieces of land resort to long term enterprises like tree growing which leads to low potato production and hence the non-selling behaviour. This contradicts [36] that argued that limited land is one of the primary reasons why the majority of smallholders do not sell staple.

The results in Table 3 further reveal that non sellers of potato earned higher monthly non-farm incomes, which were found to be thrice that of potato sellers. This explains the autarkic behaviour that stems from allocating more labour to non-farm activities than that allocated to growing potato, leaving little or no surplus labour for potato. [37] found a significantly negative effect of farm output on farmers' off-farm work hours which supported this result.

\subsection{Smallholder Farmer Participation in the Potato Market}

Following a two-stage Heckman model, the factors that influence the decision to sell to a market by smallholder farmers were regressed in the first stage, upon selling or not selling potato in the market in the last two seasons of the research period as shown in Table 4.

Table 2. Explanatory variables and hypothesised relationship with market participation level.

\begin{tabular}{cl}
\hline Variable & \multicolumn{1}{c}{ Variable description } \\
\hline$S_{n}$ & Volume of potato sold in the market (kg) \\
\hline$y_{1}$ & Age of farmer (Years) \\
$y_{2}$ & Farmer's gender (1 = male, 0 = female) \\
$y_{3}$ & Farmer's household size \\
$y_{4}$ & Farmer's district of operation (Kabale) \\
$y_{5}$ & Total annual potato harvest (kg) \\
$y_{6}$ & Potato marketing experience (years) \\
& Farmer endowments (Assets) \\
$y_{7}$ & Value of farming equipment owned (UGX) \\
$y_{8}$ & Dummy (1 = possession of a bicycle or motor cycle, $0=$ otherwise) \\
$y_{9}$ & Farmer's monthly non-farm income (UGX.) \\
$y_{13}$ & Information access \\
$y_{10}$ & Distance to nearest potato market (km) \\
& Farmer is a member of a group or cooperative \\
\hline &
\end{tabular}


Table 3. Characteristics of sampled potato selling and non selling farmers.

\begin{tabular}{lccc}
\hline \multirow{2}{*}{ Characteristic (Variable) } & Overall $\mathrm{n}=200$ & Potato sellers $\mathrm{n}=165$ & Non sellers $\mathrm{n}=35$ \\
\cline { 2 - 3 } & Mean & Mean & 39.46 \\
\hline Farmer age (years) & 41.11 & 41.45 & $5.29^{*}$ \\
Farmer's household size & 6.55 & 6.81 & 2.46 \\
Number of annual extension visits & 2.45 & 2.45 & $2.195^{* *}$ \\
Total landholding owned (ha) & 1.411 & 2.586 & 10.54 \\
Potato farming experience (years) & 11.63 & 11.86 & 7.74 \\
Farmer's education level (school years) & 7.00 & 6.84 & 126897.10 \\
Value of farming equipment(UGX) & 147612.50 & 152006.70 & $4.61^{* *}$ \\
Distance from home to market (km) & 7.33 & 7.91 & 76400.00 \\
Farmer's non-farm income (UGX) & 60190.00 & 56751.52 & $14.30^{*}$ \\
\hline Farmer gender (male) & & Percentages & 77.10 \\
Road condition to market (good) & 79.00 & 79.40 & 8.60 \\
Farmer having other food sources & 11.50 & 12.10 & 82.90 \\
Access to a village market & 82.00 & 81.80 & 34.50 \\
Membership to a farmer group/cooperative & 36.00 & 27.30 & 42.90 \\
\hline
\end{tabular}

Significant level: ${ }^{*}=10 \% ;{ }^{* *}=5 \% ;{ }^{* *}=1 \%$.

Table 4. Factors that determine the decision by a smallholder farmer to participate in the market.

\begin{tabular}{lc}
\hline $\begin{array}{c}\text { Dependent Variable: does farmer sell any potato in the market? } \\
\text { (Yes }=1, \text { No }=0)\end{array}$ & Coefficient \\
\hline Farmer's age (years) & $0.0065^{* * *}(0.0014)$ \\
Average price of potato (UGX) & $0.0005^{* * *}(0.0001)$ \\
Distance to the nearest market (Km) & $0.0081^{* * *}(0.0021)$ \\
Farmer sex (male) & $0.2566^{* * *}(0.0467)$ \\
Household size & $0.0023(0.0047)$ \\
Potato farming experience (years) & $0.0004(0.0019)$ \\
Road condition to nearest market (good) & $0.0173(0.0420)$ \\
Number of annual extension visits & $0.0143^{* * * *}(0.0054)$ \\
Farmer has other food sources other than potato & $0.0836^{* * *}(0.0346)$ \\
Farmer's education level (years) & $0.0137^{* * * *}(0.0039)$ \\
Monthly non farm income (UGX) & $-3.05 \mathrm{e}^{-007^{* * *}}(1.51 \mathrm{e}-07)$ \\
Access to a village market & $0.0651^{* *}(0.0322)$
\end{tabular}

UGX means Uganda Shillings and at the time of this study 1 USD = 2480 UGX; Standard errors in parentheses; Significant level: ${ }^{*}=10 \% ;^{* * *}=5 \% ;^{* * * *}=1 \%$. 


\subsubsection{Factors Affecting the Decision to Participate in the Market by a Smallholder Farmer}

Sex of household head had a positive and significant $(\mathrm{P} \leq 0.01)$ impact on the decision to participate and how much potato to sell in the market (Table 4). In most cases it is the males in a family who make the decisions on whether to sell potato or not and how much. This means that females are less likely to participate in the whole process of selling potato and price and other transactional bargaining. [38] showed that women rarely had similar access to assets and markets as men, which led to different levels of participation in cash crop markets. Related to that, the authors got results that indicated female farmers selling coffee in Uganda getting significantly lower prices for coffee sold in the same market with male farmers. [39] also supported this finding by indicating that female farmers grow subsistence crops for food security and cash crops meant for cash income are grown mainly by male farmers to cater for cash needs of the household.

The results also revealed that having other food sources in the farmer's household had a positive coefficient and significant $(\mathrm{P} \leq 0.05)$ effect on the decision to participate in the potato market. This is because since potato is a food as well as a cash crop, presence of other sources of food ensures surplus potato oriented towards the market. [40] found that cash crops did not appear to adversely affect a household's staple food production.

The results in Table 4 also revealed that price of potato had a positive and significant $(P \leq 0.01)$ influence on the decision to participate in the potato market. This is because many farmers respond to higher prices because it means getting higher incomes from their produce. Farmers tend to study price trends over seasons and can appropriately predict and respond to the prices. [17] supported this argument and result by stating that unfavourable prices may affect household incomes and consumption adversely.

Results of the second stage of the Heckman model that depict the factors that influence the farmers' level of participation in the potato market are shown in Table 5.

In addition, farmer's age had a positive and significant $(\mathrm{P} \leq 0.01)$ impact on the decision to participate in the potato market. This is because many decisions made in the household on whether to sell or not depend on ones position in the order of hierarchy in headship of the family. Older members of the family tend to make the key decisions that affect the family welfare. [32] asserted that age is an indicator of the position of the household in the life cycle and ability to comprehend and use accessed market information. [21] also found a positive relation between age and farmer market participation with older farmers selling higher proportions of their produce to the market.

Access to a village market also had a positive coefficient and significantly $(\mathrm{P} \leq 0.05)$ influenced the potato farmer's decision to participate in the market (Table 4). This result is explained by the fact that village markets

Table 5. Factors affecting the volume of potato sold by a farmer in a market.

\begin{tabular}{|c|c|}
\hline Selection dependent variable: annual potato sales (kg) & Coefficient \\
\hline Distance from home to nearest market $(\mathrm{km})$ & $-0.0072(0.0308)$ \\
\hline Farmer's sex (Male $=1$, female $=0$ ) & $1.8884^{* * *}(0.6107)$ \\
\hline Farmer's non farm income (UGX) & $-4.15 \mathrm{e}^{-06^{* * *}}(1.45 \mathrm{e}-06)$ \\
\hline Farmer’s potato marketing experience (years) & $0.0539(0.0307)$ \\
\hline Membership to a cooperative or group & $1.0889^{*}(0.6653)$ \\
\hline Transport cost for $100 \mathrm{Kg}$ potato bag to market (UGX) & $-0.0001(0.0001)$ \\
\hline Value of farming equipment owned (UGX) & $1.38 \mathrm{e}^{-07}\left(1.53 \mathrm{e}^{-06}\right)$ \\
\hline Availability of a village market & $0.1919(0.4006)$ \\
\hline Age of farmer (years) & $-0.0106(0.0189)$ \\
\hline Household size & $-0.0599(0.0733)$ \\
\hline Constant & $2.2133(1.1292)$ \\
\hline
\end{tabular}


are meeting points for buyers and potato sellers where there is free haggling which leads to better prices than selling at the farm gate. This reveals an important aspect of rural agricultural trade where farmers and traders from different areas converge and carry out commodity market exchanges on given market days and times. By having a closer place where to sell their produce, farmers reduce on transaction costs and interface with more market opportunities of selling directly to buyers rather than through brokers. [41] in support of this kind of arrangement, recommended strengthening market access by smallholders by implementing policies that organise producers to reduce number of intermediaries in input and output markets. Farmers who have access to village market arrangements usually produce and send more to the market than their counterparts without such opportunities. [42] found that physical infrastructure like market sites can increase the efficiency of both marketing and production of agricultural products.

To access market information and production knowledge, smallholders have to interface with a number of market and institutional actors who include traders, brokers and extension agents. In this study, results indicated that the number of extension visits from government workers had a positive and significant $(\mathrm{P} \leq 0.01)$ effect on the decision to participate in the market. This is because extension workers usually provide information on market availability as well as information on new and improved varieties that enhances the farmer's knowledge and provide a range and choice of market opportunities. [21] also got a similar result when they found a positive and significant effect of extension access on the volume of teff sold. [32] agreed with this argument by stating that to commercialise, the most important factors appear to be improved access to markets, information and risk reduction. [17] also supported the argument by stressing that smallholder commercialisation could be seen as the strength of the linkage between farm households and markets at a given point in time.

The results in Table 4 indicate that education had a positive and significant $(\mathrm{P} \leq 0.01)$ effect on smallholder farmer's decision to enter the potato market. This can be highly attributed to the fact that education empowers a farmer to make informed decisions and identify market opportunities where they exist. [43] however found results that indicated that farmer's ability to produce and sell more in a market was highly and positively related to their education levels. The authors asserted that farmers, who had attained secondary education and had combined it with informal education, were more likely to produce and sell more.

Distance to the nearest town had a positive and significant $(\mathrm{P} \leq 0.01)$ effect on potato farmer's decision to participate in the market. This is because the nearer to town the easier it is to access buyers who offer better payment terms than in the case of farmers far away from towns. This is counter intuitive as earlier literature from Mozambique by [32] showed, even though they offered a possible explanation that since towns tend to be market centres as well, off farm employment opportunities are much better close, to the extent that off farm employment and reliance on output markets are substitutes.

Though not significant, smallholder farmer's household size, potato farming experience and good road condition to the nearest market had a positive sign (Table 4) meaning they promote a farmer's decision to enter the market. [31] also found a positive but no significant effect of size of household on entering the market as a seller. [44] explained that large households seem to have higher opportunity costs, perhaps which is reflected in the fact that they have lower per-capita income and hence less surplus to purchase capital equipment to switch to the market. [45] found that the state of bad roads negatively impacted on farmers' access to urban markets, hence a hindrance to smallholder commercialisation and increased incomes.

\subsubsection{Factors that Influence the Volumes Sold into the Market by Smallholder Farmers}

Table 5 results indicate that off farm income earned by a potato farmer was found to negatively and significantly, $(\mathrm{P} \leq 0.05)$ affect volumes of potato sold in the market. Farmers engaged in off-farm work and earning incomes other than potato income tend to dedicate less time to production and marketing of potato, which possibly results into smaller quantities sold. [46] found a negative relationship between off farm income and agricultural sales which the authors attributed to time constraints on agricultural production and farm management since off farm employment competes with farm activities for the time resource. [47] added that non-farm incomes of rural households may be derived from casual labour hire, wage employment, private business activity (self-employed) or remittances [24] [48] in support of the importance of off farm income to the smallholders, contended that in the presence of working capital constraints, off-farm earnings may be essential to maintaining a viable farm that requires purchased inputs or that cannot generate enough cash income to satisfy the household's cash requirements.

The gender of the farmer had a positive and significant $(\mathrm{P} \leq 0.05)$ effect on the volumes of potato sold into the 
market. Hence, by being male, a farmer had higher chances of selling more potato to the market because male farmers have more contacts that are social with both potato buyers and their agents whom they often meet in trading centres. Males dominate in selling potato to the market and as expected, they make the decisions that affect all family members. Female farmers lack such contacts and are in most cases excluded from direct transactional negotiations with buyers. [11] found that male gender of farmer positively and significantly influenced farmer's volume of sales in the market. The author stated that the reason is that women spend much of their time doing domestic work and allocate less time to other matters like market transactions.

Related to the above, a potato farmer's membership in a group or marketing cooperative positively and significantly ( $\mathrm{P} \leq 0.1$ ) influenced the volumes of potato produce sold in a market (Table 5). The main reason for this was that working in a group creates synergy among the farmers and enables them to access market information as well as sharing experiences. [49] [50] while studying smallholder agricultural commercialization and collective action in Kenya also found a positive and significant influence of membership in a group on the level of commercialization. The authors stated that membership to a farmers' group improves access to banana technology, training and output markets and consequently increasing expected profits.

\section{Conclusions and Recommendations}

The findings of the study overwhelmingly support the hypothesis that transaction costs play a big role in impeding smallholders from entering markets. The failure of farmers to access information on the markets through long distances and lack of access to village market arrangements seemed to lock out many of them from making decisions to enter the potato market to sell.

Results also revealed that once a smallholder farmer decides to enter the market to sell, household characteristics and farmer endowments are the key factors that influence how much will be sold into the market. Factors like gender, membership to a farmers' group or cooperative came out to significantly influence the level of market participation in form of how much is sold.

In light of these findings, it is therefore recommended that potato farmers be sensitised on investment of external incomes into potato production as a profitable venture and policy makers should also promote the village market collection centres. Membership to a farmer group or cooperative being a key factor in enhancing the volumes of potato sold, it is recommended that policy makers should promote collective action among smallholders because it eases access to production and marketing information as well as cheaper inputs.

\section{Acknowledgements}

This paper is based on earlier research work done by the authors on Irish Potato with support from the Regional University Forum for Capacity Building in Agriculture (RUFORUM) and Belgium Technical Cooperation (BTC) in Uganda. However, the views expressed herein do not necessarily represent the position of any of these organizations. All errors in interpretation are the authors' own.

\section{References}

[1] FAO (2008) Workshop to Commemorate the International Year of Potato. Bangkok, 6 May 2008 Proceedings. www.potato2008.org/en/potato/index/html.

[2] Schwartzmann, M. (2010) Potato-A World Production, a European Business. 12th Euro Blight Workshop Arras, France, 3-6 May 2010, 11-16.

[3] Kinyua, Z.M., Bararyenya, A., Schulte-Geldermann, A., Obura, B.O., Kashaija, I.N., Tindimubona, S., Opio, F., Oyena, D., Rwomushana, I., Murithi, W.M., Kinoti, J., Namugga, P., Kimoone, G., Inamahoro, M., Niko, N. and Ndayihanzamaso, P. (2008) Overcoming Seed Potato Quality Constraints to Tackle Food Insecurity and Poverty in Eastern and Central Africa in the 21st Century. African Crop Science journal, 9, 279-285.

[4] Ferris, R.S.B., Okoboi, G., Crissman, C., Ewell, P. and Lemaga, B. (2001) Uganda's Irish Potato Sector. IITAFOODNET, CIP, PRAPACE, CGIAR and ASARECA at the Government of Uganda's Conference on Competitiveness of Selected Strategic Exports.

[5] Jari, B. and Fraser, G.C.G. (2009) An Analysis of Institutional and Technical Factors Influencing Agricultural Marketing amongst Smallholder Farmers in the Rift Valley, Eastern Cape Province, South Africa. African Journal of Agricultural Research, 4, 1129-1137.

[6] Ruijs, A., Schweigman, C. and Lutz, C. (2004) The Impact of Transport and Transaction-Cost Reductions on Food 
Markets in Developing Countries: Evidence from Tempered Expectations for Burkina Faso. Elsevier Agricultural Economics, 31, 219-228. http://dx.doi.org/10.1016/j.agecon.2004.09.009

[7] Nkonya, E. and Kato, E. (2001) Agricultural Input Marketing in Uganda International Food Policy Research Institute (IFPRI). The IFPRI Policy Workshop, Kampala, 25-26 June 2001.

[8] Aliguma, L., Magala, D. and Lwasa, S. (2007) Uganda: Connecting Small-Scale Producers to Markets: The Case of the Nyabyumba United Farmers Group in Kabale District. Regoverning Markets Innovative Practice series, IIED, London.

[9] Okoboi, G. (2001) The Marketing Potential of Potatoes in Uganda and Market Opportunities for Rwanda. International Institute of Tropical Agriculture, Ibadan.

[10] World Bank (2008) World Development Report, Agriculture for Development. The World Bank, Washington DC.

[11] Wang'ombe, J.G. (2008) The Potato Value Chain in Kenya and Uganda. Maastricht School of Management, DBA Assignment.

[12] Ministry of Finance Planning and Economic Development, MFPED (2004) Background to the Budget for Financial Year 2004/05 "Promoting Economic Growth and Reducing Poverty through Public Expenditure” (Abstract), MFPED, Kampala.

[13] FAO (2010) Strengthening Potato Value Chains, Technical and Policy options for Developing Countries. The Food and Agriculture Organization of the United Nations and the Common Fund for Commodities. Rome.

[14] Jagwe, J.N. (2011) Impact of Transaction Costs on the Participation of Smallholder Farmers and Intermediaries in the Banana Markets of Burundi, Democratic Republic of Congo and Rwanda. Ph.D. Thesis (Agricultural Economics), University of Pretoria, Pretoria, submitted.

[15] Shepherd, A. (2007) Approaches to Linking Producers to Markets. Agricultural Management, Marketing and Financial Occasional Paper 13. Food and Agricultural Organisation of the United Nations, Rome. Rural Infrastructure and Agro-Industries Division.

[16] Njuki, J., Kaaria, S., Sanginga, P., Kaganzi, E. and Magombo, T. (2006) Empowering Communities through Market Led Development. Community Agro-Enterprise Experiences from Uganda and Malawi.

[17] Jaleta, M., Gebremedhin, B. and Hoekstra, D. (2009) Smallholder Commercialisation: Processes, Determinants and Impact. Discussion Paper No. 18: Improving Productivity and Market Success of Ethiopian Farmers, Improving Market Opportunities, International Livestock Research Institute, Nairobi.

[18] Holden, S.T. and Binswanger, H. (1998) Small-Farmer Decision Making, Market Imperfections, and Natural Resource Management in Developing Countries. In: Lutz, E., Binswanger, H., Hazell, P. and McCalla, A., Eds., Agriculture and the Environment. Perspectives on Sustainable Rural Development, The World Bank, Washington DC, 50-70.

[19] Jagwe, J.N., Ouma, E. and Machethe, C. (2009) Transaction Costs and Smallholder Farmers' Participation in Banana Markets in the Great Lakes Region. Centre of Evaluation for Global Action, UC Berkeley.

[20] Eskola, E. (2005) Commercialisation and Poverty in Tanzania: Household-Level Analysis. Discussion Paper, Department of Economics, University of Copenhagen, Copenhagen.

[21] Gebremedhin, B. and Hoekstra, D. (2007) Cereal Marketing and Household Market Participation in Ethiopia: The Case of Teff, Wheat and Rice. AAAE Conference Proceedings, 2007, 243-252.

[22] Lerman, Z. (2004) Policies and Institutions for Commercialization of Subsistence Farms in Transition Countries. Journal of Asian Economics, 15, 461-479. http://dx.doi.org/10.1016/j.asieco.2004.05.004

[23] Boughton, D., Mather, D., Barrett, C.B., Benfica, R., Danilo, A., Tschirley, D. and Cunguara, B. (2007) Market Participation by Rural Households in a Low-Income Country: An Asset-Based Approach Applied to Mozambique. Department of Agricultural Economics, 213 E Agriculture Hall, Michigan State University, East Lansing.

[24] Barret, C.B. (2007) Smallholder Market Participation: Concepts and Evidence from Eastern and Southern Africa. Food Policy, 4, 33.

[25] Pravakar, S., Castellanos, I.V. and Rahut, D.B. (2010) Commercialization of Agriculture in the Himalayas. IDE Discussion Paper No. 265.

[26] Enete, A.A. and Igbokwe, E.M. (2009) Cassava Market Participation Decision of Producing Households in Africa. Tropicultura, 27, 129-136.

[27] Omiti, J.M., Otieno, D.J., Nyanamba, T.O. and McCullough, E. (2009) Factors Influencing the Intensity of Market Participation by Smallholder Farmers: A Case Study of Rural and Peri-Urban Areas of Kenya. African Journal of Agricultural and Rural Economics, 3, 57-82.

[28] Johnson, M., Hazell, P. and Gulati, A. (2003) The Role of Intermediate Factor Markets in Asia's Green Revolution: Lessons for Africa? Bruce Gardner, University of Maryland, College Park, Maryland.

[29] Jayne, T.S., Mather, D. and Mghenyi, E. (2010) Principal Challenges Confronting Smallholder Agriculture in SubSaharan Africa. World Development, 38, 1384-1398. http://dx.doi.org/10.1016/j.worlddev.2010.06.002 
[30] Heckman, J.J. (1979) Sample Selection Bias as a Specification Error. Econometrica, 47, 153-161. http://dx.doi.org/10.2307/1912352

[31] Goetz, S.J. (1992) A Selectivity Model of Household Food Marketing Behaviour in Sub-Saharan Africa. American Journal of Agricultural Economics, 74, 444-452. http://dx.doi.org/10.2307/1242498

[32] Heltberg, R. and Tarp, F. (2001) Agricultural Supply Response and Poverty in Mozambique. Institute of Economics, University of Copenhagen: Studiestraede, Copenhagen.

[33] Winship, C. and Mare, R.D. (1992) Models for Sample Selection Bias. Annual Review of Sociology, 18, $327-350$. http://dx.doi.org/10.1146/annurev.so.18.080192.001551

[34] Olwande, J. and Mathenge, M. (2012) Market Participation among Poor Rural Households in Kenya. The International Association of Agricultural Economists (IAAE) Triennial Conference, Foz do Iguaçu, 18-24 August 2012.

[35] Green, W.H. (2003) Econometric Analysis. 5th Edition, Prentice Hall, Bergen County, NJ.

[36] COMESA (2010) Smallholder Marketing Behaviour and Urban Consumption Patterns in Eastern and Southern Africa. COMESA Alliance for Commodity Trade in Eastern and Southern Africa.

[37] Lien, G., Kumbhakar, S.C. and Hardakar, J.B. (2010) Determinants of Off-Farm Work and Its Effects on Farm Performance: The Case of Norwegian Grain Farmers. Journal of Agricultural Economics, 41, 577-586. http://dx.doi.org/10.1111/j.1574-0862.2010.00473.x

[38] Vigneri, M. and Vargas, H.R. (2011) Mainstreaming Gender Sensitivity in Cash Crop Markets Supply Chains. Working Paper No. 11-08, ESA, FAO. http://www.fao.org/docrep/013/am313e/am313e00.pdf.

[39] Doss, C.R. (2001) Designing Agricultural Technology for African Women Farmers: Lessons from 25 Years of Experience. World Development, 29, 2075-2092. http://dx.doi.org/10.1016/S0305-750X(01)00088-2

[40] Srivastava, L. (1995) Cash Crop Adoption by Peasant Households: An Empirical Analysis from the Middle Mountains of Nepal. A Master of Science Thesis, University of British Columbia, Vancouver.

[41] Fletschner, D.K. and Zepeda, L. (2002) Efficiency of Small Landholders in Eastern Paraguay. Journal of Agricultural and Resource Economics, 27, 554-572.

[42] Von Oppen, M., Njehia, B.K. and Ijaimi, A. (1997) POLICY ARENA the Impact of Market Access on Agricultural Productivity: Lessons from India, Kenya and the Sudan. Journal of International Development, 9, 117-131. http://dx.doi.org/10.1002/(SICI)1099-1328(199701)9:1<117::AID-JID416>3.0.CO;2-T

[43] Odulaja, A. and Kiros, F.G. (1996) Modelling Agricultural Production of Small-Scale Farmers in Sub-Saharan Africa: A Case Study in Western Kenya. Agricultural Economics, 14, 85-91. http://dx.doi.org/10.1016/0169-5150(96)01184-X

[44] Cadot, O., Dutoitz, L. and Olarreagax, M. (2006) How Costly Is It for Poor Farmers to Lift Themselves Out of Subsistence? World Bank Policy Research Working Paper 3881, SSRN.

[45] Makhura, M.T. (2001) Overcoming Transaction Costs Barriers to Market Participation of Smallholder Farmers in the Northern Province of South Africa. A PhD Thesis Submitted in Partial Fulfillment of the Requirements for the Degree of in the Department of Agricultural Economics, Extension and Rural Development Faculty of Natural and Agricultural Sciences University of Pretoria, Pretoria, June 2001.

[46] Rios, A.R., Shively, G.E. and Masters, W.A. (2008) Linkages between Market Participation and Productivity: Results from a Multi-Country Farm Household Sample. The AAEA Annual Meeting, Orlando, Florida, 27-29 July 2008.

[47] Poulton, C. and Leavy, J. (2007) Commercialisations in Agriculture. A Working Paper, Future Agricultures, School of Oriental and African Studies (SOAS), University of London, London.

[48] Reardon, T., Timmer, P.C., Barret, C.B. and Berdegue, J. (2003) The Rise of Supermarkets in Africa, Asia and Latin America. American Journal of Agricultural Economics, 85, 1140-1146. http://dx.doi.org/10.1111/j.0092-5853.2003.00520.x

[49] Abera, G. (2009) Commercialisation of Smallholder Farming: Determinants and Welfare Outcomes. A Cross Sectional Study in Enderta District, Tigrai Ethiopia. Masters Thesis, The University of Agder, Kristiansand.

[50] Fischer, E. and Qaim, M. (2012) Gender, Agricultural Commercialisation, and Collective Action in Kenya. The International Association of Agricultural Economists (IAAE) Triennial Conference, Foz do Iguaçu, 18-24 August 2012. 
Scientific Research Publishing (SCIRP) is one of the largest Open Access journal publishers. It is currently publishing more than 200 open access, online, peer-reviewed journals covering a wide range of academic disciplines. SCIRP serves the worldwide academic communities and contributes to the progress and application of science with its publication.

Other selected journals from SCIRP are listed as below. Submit your manuscript to us via either submit@scirp.org or Online Submission Portal.
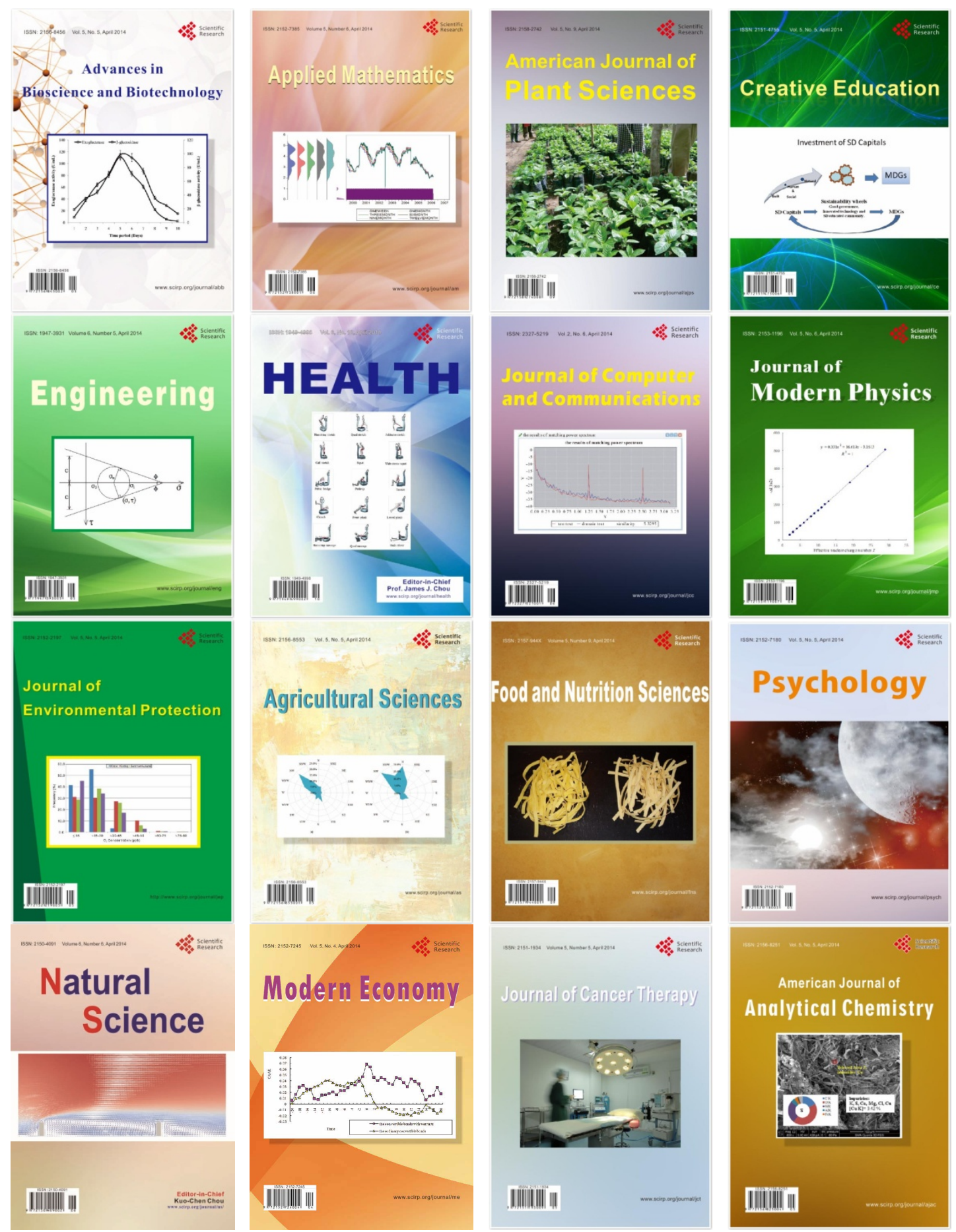